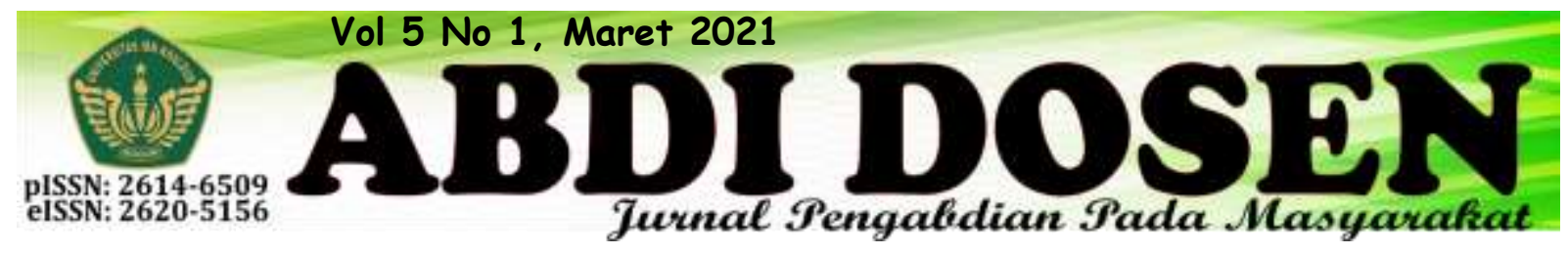

\title{
PEMBERDAYAAN MASYARAKAT PEMBUATAN TEPUNG AMPAS KELAPA DI KECAMATAN TANANTOVEA KABUPATEN DONGGALA
}

Sri Hastuti Virgianti Pulukadang ${ }^{1}$, Jamaludin M. Sakung ${ }^{2}$, Sitti Rahmawati ${ }^{3}$, Meida Esterlina

\author{
Marpaung ${ }^{4}$ \\ pulukadangsrihastutivirgianti@gmail.com ${ }^{1}$ \\ jamal_utd@yahoo.com ${ }^{2}$ \\ sittirahmawati@yahoo.com $^{3}$ \\ chemistry.meida@gmail.com ${ }^{4}$ \\ Universitas Tadulako, Palu
}

\begin{abstract}
ABSTRAK
Tanaman kelapa sebagai tanaman tropis, merupakan tanaman komoditi tumbuh dan berkembang dengan baik di Indonesia. Secara khusus, tanaman ini tumbuh di sepanjang pasir pantai dan secara umum dapat tumbuh di dataran tinggi serta lereng gunung. Salah satu wilayah penghasil kelapa yang melimpah adalah Sulawesi Tengah (Kabupaten Donggala). Ampas kelapa memiliki keunggulan sebagai pendukung kelestarian ketahanan pangan, hal tersebut ditunjang oleh potensi produksi yang tinggi. Untuk meningkatkan pemanfaatan limbah ampas kelapa salah satunya dapat dilakukan dalam proses pembuatan tepung. permasalahan yang dihadapi oleh mitra adalah Kurangnya informasi yang didapatkan oleh petani kelapa tentang pembuatan tepung ampas kelapa yang bernilai gizi dan dapat dimanfaatkan sebagai pengganti tepung terigu untuk produk pangan lainnya. Solusi pemecahan masalahnya dilakukan melalui pelatihan ataupun workshop dan bimbingan tentang pembuatan tepung ampas kelapa bagi para petani kelapa. Pembuatan tepung dari ampas kelapa dan olahan makanan sehat berbasis tepung ampas kelapa tersebut dapat meningkatkan kesehatan dan kesejahteraan masyarakat kecamatan tanantovea khususnya ibuibu.
\end{abstract}

Kata Kunci: Ampas kelapa, gizi, kelapa, tepung

\section{PENDAHULUAN}

Kecamatan Tanantovea Kabupaten Donggala terdiri dari 10 desa dengan penduduk sebanyak 19.457 jiwa. Dan sebagian besar bermata pencaharian sebagai petani. Penduduk yang bekerja sebagai petani di Kecamatan Tanantovea umumnya mengusahakan tanaman perkebunan. Terdapat empat jenis tanaman perkebunan yang diusahakan yaitu kelapa, kakao, kopi dan lada.
Kelapa adalah tanaman perkebunan terluas dan diikuti kakao. Luas lahan kelapa mencapai 2.511 hektar dengan produksi mencapai 2.650 ton diikuti kakao mencapai luas 356 Hektar dengan produksi mencapai 390 ton. Potensi limbah dari kelapa yang ada berupa limbah ampas kelapa ini sangat melimpah jumlahnya, dan jika dibiarkan sampai membusuk. Pembusukan dari limbah ini menimbulkan 
bau yang kurang sedap dan dalam waktu lama akan menurunkan kualitas lingkungan, berikut gambar ampas kelapa yang siap dibuang kelingkungan.

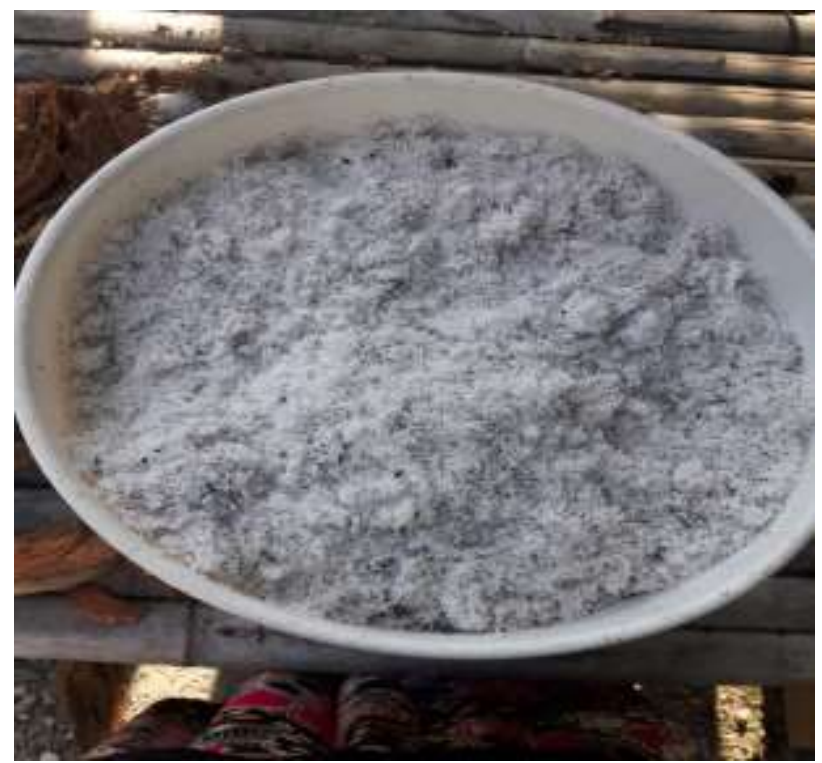

Gambar 1. Ampas Kelapa

Pengabdian masyarakat dalam membantu memanfaatkan potensi limbah yang melimpah ini, maka program pengabdian diarahkan untuk melakukan pendampingan kepada masyarakat berupa teknik pembuatan tepung dari ampas kelapa. Kendala yang dihadapi masyarakat pada umumnya belum kreatif menciptakan sesuatu yang baru, padahal banyak hasil pertanian yang diperoleh diwilayah tersebut. Olehnya melalui pengabdian kepada masyarakat kami akan memberikan salah satu bentuk pelatihan bagaimana pembuatan tepung limbah ampas kelapa sebagai bahan pengganti tepung terigu yang saat ini digunakan sebagai bahan pembuatan kue dan produk lainnya. Tentunya pada pelatihan ini berkaitan erat dengan proses dan peralatan yang digunakan seperti produksinya cepat, sederhana dan murah, memiliki kemampuan untuk diolah menjadi produkproduk yang lebih berkualitas, dan dapat ditambahkan pada produk-produk pangan lainnya (Angelia, 2016; Widarta, Suter,
Yusa, Wiadnyani, \& Nocianitri, 2013).

Tepung yang dihasilkan untuk dikonsumsi sebagai bahan makanan telah diatur sesuai dengan standar nasional yang dilakukan oleh Badan Standarisasi Nasional, dimana tepung harus memenuhi uji standar kelayakan yang dimaksudkan untuk melindungi kesehatan konsumen. Daging buah kelapa adalah komponen utama yang dapat diolah menjadi berbagai produk bernilai tinggi. Mutu bahan baku dari daging buah kelapa dipengaruhi oleh karakter fisiko-kimia komponen buah kelapa, yang secara langsung dipengaruhi oleh jenis dan umur buah kelapa; secara tidak langsung dipengaruhi oleh lingkungan tumbuh dan pemeliharaannya (Mahmud \& Ferry, 2015).

Kandungan gizi tepung ampas kelapa mengandung karbohidrat dalam jumlah yang lebih rendah yaitu sekitar 33,64125 persen, dari tepung terigu (73,52 persen). Kandungan protein tepung ampas kelapa relative cukup rendah yaitu 5,78725 persen, daripada tepung terigu $(13,51$ 
persen). Kandungan lemak tepung ampas kelapa cukup tinggi dari tepung terigu (38,2377 persen). Kandungan serat kasar tepung ampas kelapa cukup tinggi yaitu $(15,068865)$ persen, lebih tinggi dari tepung terigu (0,25 persen) (Hasan, 2018; Putri, 2014).

Berdasarkan analisis tersebut dan didukung tawaran pengabdian kepada masyarakat kepada para petani kelapa diharapkan pengolahan limbah ampas kelapa menjadi tepung yang mengandung nilai gizi bagi kebutuhan tubuh, dan juga memberikan pengaruh yang besar dalam peningkatan nilai ekonomi masyarakat.

\section{METODE PELAKSANAAN}

Pelaksanaan pengabdian untuk solusi permasalahan yang dihadapi oleh masyarakat sasaran dibagi ke dalam tiga tahapan utama yaitu : (1). Persiapan dan pembekalan, (2). Pelaksanaan, (3). Evaluasi.

\section{Persiapan}

Persiapan kegiatan pengabdian ini meliputi:

a. Penentuan lokasi sasaran pengabdian.

b. Rekrutmen masyarakat peserta pengabdian.

c. Observasi lapangan dan sosialisasi kepada masyarakat sasaran

kegiatan persiapan dilakukan untuk menyamakan persepsi dan pemahaman tentang latar belakang pelaksanaan pengabdian, tujuan dan sasaran kegiatan, rencana dan implementasi program/kegiatan serta monitoring dan evaluasi program/kegiatan.

\section{Pelaksanaan}

Pelaksanaan program pengabdian direncanakan berlangsung selama 1 bulan di wilayah kecamatan Tanantovea tepatnya di 3 desa yang telah disepakati oleh Camat
Pengabdian akan dilaksanakan kepada para petani kelapa khusunya di kecamatan Tanantovea kabupaten Donggala.

Adapun permasalahan yang dihadapi oleh mitra adalah Kurangnya informasi yang didapatkan oleh petani kelapa tentang pembuatan tepung ampas kelapa yang bernilai gizi dan dapat dimanfaatkan sebagai pengganti tepung terigu untuk produk pangan lainnya.

Solusi pemecahan masalahnya dilakukan melalui pelatihan ataupun workshop dan bimbingan tentang pembuatan tepung ampas kelapa bagi para petani kelapa.

Tanantovea yakni desa Wombo Induk, Wombo Kalonggo dan Wombo Mpanau. Dalam pelaksanaannya metode yang digunakan adalah penyuluhan, pelatihan dan demontrasi.

Langkah-langkah yang diperlukan untuk mengatasi permasalahan yang dihadapi kelompok sasaran yaitu:

\section{a. Pembentukan Kelompok}

Kelompok sasaran adalah kelompok masyarakat produktif dalam satu dusun/kampung. Pendekatan yang digunakan adalah partisipatif, dengan melibatkan kelompok sasaran. Masyarakat kelompok sasaran dikelompokkan berdasarkan domisili/tempat tinggal pada masing-masing dusun. Pada setiap desa dibentuk dua kelompok produktif masyarakat dengan minimal masingmasing 5 (lima) orang setiap kelompok produktif

sebagai peserta program, sehingga secara keseluruhan berjumlah 30 orang dari 3 desa yang menjadi lokasi pengabdian.

b. Sosialisasi Program pengabdian

Kegiatan sosialisasi akan dilaksanakan 
di masing-masing ruang pertemuan masyarakat/Balai Desa di masing-masing desa. Sosialisasi dilaksanakan dengan tujuan menyampaikan maksud, tujuan dan sasaran kegiatan pengabdian serta membuat kesepakatan awal untuk rencana tindak lanjut yang akan dilakukan. Kegiatan sosialisasi dilakukan terhadap

\section{HASIL dan PEMBAHASAN}

Pelaksanaan pengabdian diawali dengan sosialisasi dengan instansi terkait, camat, kepala Desa setempat). Sosialisasi ini bertujuan untuk memberi informasi kepada instansi terkait mengenai pelaksanaan pengabdian dan agar peserta mengetahui maksud dari pelaksanaan program tersebut oleh tim pelaksana agar tidak terjadi kesalahan informasi. Selanjutnya setelah penyampaian rencana program secara menyeluruh dilanjutkan dengan pemberian pelatihan yang berkenaan dengan tema pembuatan olahan makanan sehat berbasis labu siam untuk meningkatkan kesehatan dan kesejahteraan masyarakat kecamatan palolo kabupaten kelompok sasaran dan anggota masyarakat lainnya, tokoh/pemuka masyarakat serta petugas pelaksana dari instansi terkait.

\section{c. Pelatihan}

Pelatihan dilakukan pada masyarakat di desa dan diikuti oleh 10 orang peserta untuk setiap desa.

sigi.

Pelatihan dilaksanankan di aula Desa Wombo (Gambar 2), peserta pelatihan adalah ibu-ibu PKK Desa Wombo. Materi pelatihan meliputi: Pelatihan Good Manufacturing Practice (GMP) cara memproduksi tepung ampas kelapa yang baik adalah tuntunan bagi pelaku usaha dalam melakukan produksi produknya, Pelatihan Pengemasan Produk, yaitu cara mengemas produk tepung ampas kelapa yang baik, Pembuatan Tepung dari ampas kelapa, Pengolahan berbagai produk berbasis tepung ampas kelapa (kue kering dan lainnya) (Bakara \& Tarigan, 2018).

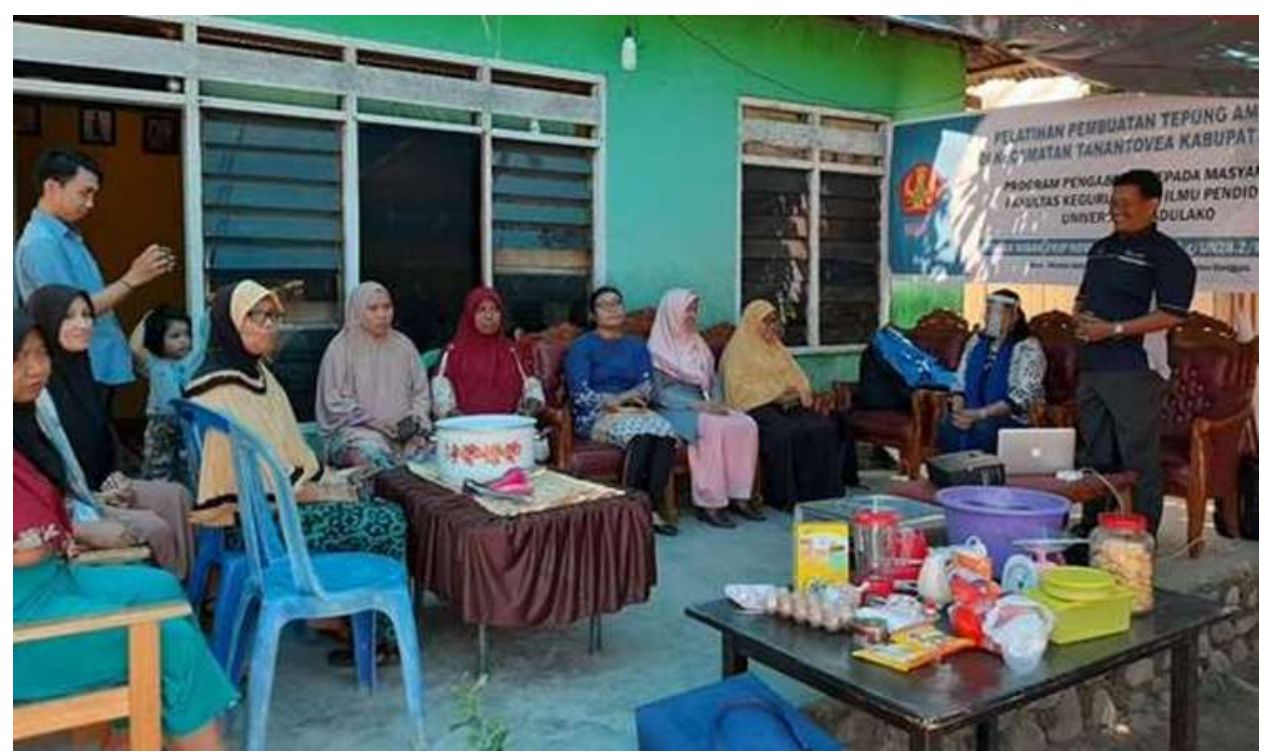

Gambar 2. Presentase Pembuatan Tepung Ampas kelapa Sumber: dokumentasi Pengabdian Masyarakat 
Praktek dimulai dari pembuatan Tepung ampas kelapa dilanjutkan dengan pembuatan produk olahan berbasis tepung ampas kelapa (kue kering berbasis ampas kelapa), peserta dibagi menjadi 2 kelompok yang akan didampingi oleh tim pelaksana pengabdian dan tenaga lapangan (Gambar 3). Kegiatan yang dilaksanakan pada kerja praktek adalah para peserta dibimbing/ didampingi mulai dari menyiapkan ampas kelapa, oven dan lainnya, ampas kelapa di oven hingga kering, selanjutnya di blender untuk mendapatkan tepung. langkah selanjutnya diolah menjadi kue kering.

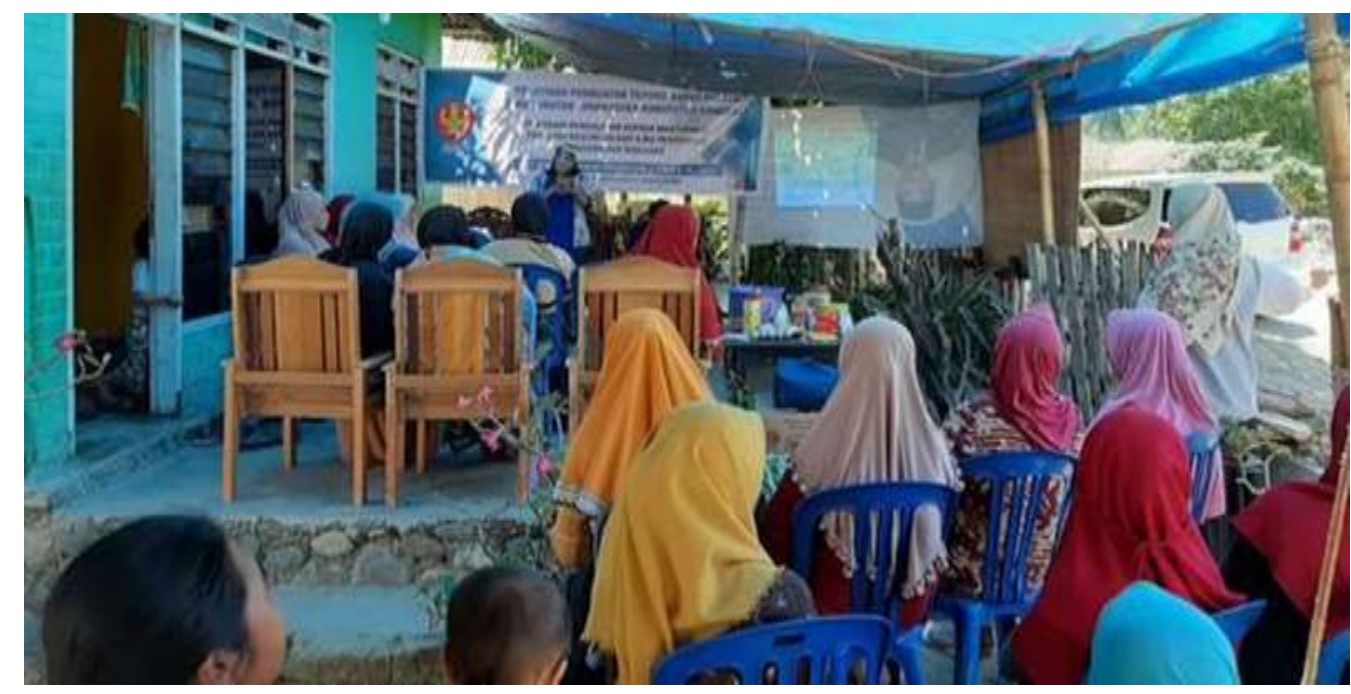

Gambar 3. Presentase Pembuatan Produk berbasis tepung ampas kelapa Sumber: dokumentasi Pengabdian Masyarakat

Produk olahan ini tergolong makanan sehat karena kandungan gizi tepung ampas kelapa yaitu mengandung karbohidrat dalam jumlah yang lebih rendah yaitu sekitar 33,64125 persen, dari tepung terigu $(73,52$ persen) (DiasMartins, Pessanha, Pacheco, Rodrigues, \& Carvalho, 2018). Kandungan protein tepung ampas kelapa relative cukup rendah yaitu 5,78725 persen, daripada tepung terigu (13,51 persen). Kandungan lemak tepung ampas kelapa cukup tinggi dari tepung terigu (38,2377 persen). Kandungan serat kasar tepung ampas kelapa cukup tinggi yaitu $(15,068865)$ persen, lebih tinggi dari tepung terigu $(0,25$ persen) (Hasan, 2018; Putri, 2014). Semua kegiatan tersebut dilakukan sedemikian rupa agar memudahkan peserta pelatihan melakukan hal tersebut secara berkelanjutan 


\section{KESIMPULAN}

Pemberdayaan masyarakat melalui pelatihan pembuatan tepung dari ampas kelapa dan olahan makanan sehat berbasis tepung ampas kelapa tersebut dapat meningkatkan kesehatan dan kesejahteraan masyarakat kecamatan tanantovea khususnya ibu-ibu. kegiatan pengabdian

\section{DAFTAR PUSTAKA}

Angelia, I. O. (2016). Analisis Kadar Lemak pada Tepung Ampas Kelapa. Jurnal Technopreneur (JTech), 4(1), 19-23.

Bakara, T. L., \& Tarigan, N. (2018). Training of Utilization of Coconut Dregs Flour and Its Processed Product to Increase Fiber Consumption in Tumpatan Village, Beringin Sub-District. Journal of Saintech Transfer, 1(1), 75-81.

Dias-Martins, A. M., Pessanha, K. L. F., Pacheco, S., Rodrigues, J. A. S., \& Carvalho, C. W. P. (2018). Potential use of pearl millet (Pennisetum glaucum (L.) R. Br.) in Brazil: Food security, processing, health benefits and nutritional products. Food research international, 109, 175186. ini dapat meningkat pengetahuan dan ketrampilan masyarakat, dalam menggerakkan potensi sumberdaya berupa limbah ampas kelapa yang dimiliki oleh masyarakat untuk peningkatan pendapatan dan kesejahteraan masyarakat berbasis inovasi teknologi dan kearifan lokal.

Hasan, I. (2018). Pengaruh perbandingan tepung ampas kelapa dengan tepung terigu terhadap mutu brownies. Gorontalo Agriculture Technology Journal, 1(1), 59-67.

Mahmud, Z., \& Ferry, Y. (2015). Prospek pengolahan hasil samping buah kelapa. Perspektif, 4(2), 55-63.

Putri, M. F. (2014). Kandungan gizi dan sifat fisik tepung ampas kelapa sebagai bahan pangan sumber serat. Teknobuga, 1(1).

Widarta, I. W., Suter, I. K., Yusa, N. M., Wiadnyani, A., \& Nocianitri, K. (2013). Pelatihan Pengolahan Tepung Ampas Kelapa Menjadi Biskuit di Desa Adat Penglipuran, Kabupaten Bangli. Buletin Udayana Mengabdi, 12(2). 